\title{
rhDNAse (Dornase alfa) and its role in the management of COVID-19
}

\author{
rhDNAz (Dornase alfa) nedir, COVID-19 tedavisinde yeri var midır?
}

\author{
Özgür Karcioğlu \\ University of Health Sciences, Dept. of Emergency Medicine, Istanbul Education and Research Hospital, Istanbul, TURKEY
}

\begin{abstract}
Neutrophil leukocytes (NL) are the fastest-reacting cells on the front line struggling against pathogenic microorganisms in the body. Swift response by the NLs in the patients with COVID-19 is useful for the body, although the untoward, inadvertently proceeding in this response is thought to enhance life-threatening pulmonary damage and pave the way to death of the patient. The phenomenon known as 'cytokine storm' is a general term describing this unwanted reaction by the body and is the result of complicated intriguing cellular and biochemical processes.

So-called "neutrophil extracellular traps" (NETS) trigger progressing to ARDS and respiratory failure in critical cases with COVID-19. rhDNAse (Dornase alfa) is an agent postulated to hydrolyze DNA networks released by the killed NLs and thus reverse the deadly process in the lungs. Its major drawbacks are cost and inability to apply to mild-to-moderate cases in order to prevent deterioration to a critical illness. Nonetheless, it can represent a promising new therapeutic modality in the future.

ÖZET

Nötrofil lökositler (NL) vücutta hastalık yapan mikroorganizmalarla savaşın en ön cephesindeki hücrelerdir ve hemen yanit verirler. COVID-19 olgularinda da NL'lerin hizla yanit vermesi olumlu, iyileștirici bir faktördür; fakat bu yanitın istenmeyen aşırı bir noktaya gelmesinin akciğer hasarını artırdı̆̆ ve ölüme giden yolu tetiklediği düşünülmektedir. 'Sitokin firtınası' kavramı bu abartılı yanıtın genel adıdır ve birçok hücresel ve biyokimyasal yanttın ilişkilerinin sonucudur. Akciğerde "neutrophil extracellular traps" (NETs) olușumu COVID-19 enfeksiyonunun ARDS'ye ve solunum yetmezliğine ilerlemesinin belirleyici sürecidir. rhDNAz (Dornase alfa) burada lökositlerden açı̆̆a çıkan DNA'ları parçalayarak süreci geriye çevirebilmektedir. Pahalılığı ve orta şiddetteki hastalarda uygulanamaması şu an çekinceleri oluştursa da gelecek için ümit veren bir tedavi modalitesi olabilir.
\end{abstract}

Key Words: rhDNAse, Dornase alfa, COVID-19, Treatment.

\section{Anahtar Kelimeler: rhDNAz,} Dornaz alfa, KOVID-19, Tedavi.

\section{GíRIŞ}

COVID-19, artmış pulmoner inflamasyon ile tetiklenen pnömonitis ve ARDS, koyu kıvam almış akciğer salgıları, yaygın akciğer hasarı ile hava yollarının tıkanmasına yol açmakta ve ölümcül yola giriş bu mekanizma ile başlamaktadır. Serumda proinflamatuar sitokinlerin artışı (sitokin firtınası) ve mikrotrombozların da bu mekanizmada rolü vardır (Şekil 1).

Birçok uzman hastalığın ağır seyretmesinin abartılmış immun yanıt ile ilişkili olduğunu düşünmektedir. Burada nötrofil lökositlerin aşırı aktivasyonunun asıl nedenlerden biri olduğu öne sürülmektedir (1). Otopsi kayıtlarında akciğerlerde nötrofil birikiminin ve infiltrasyonunun ön planda olduğu bildirilmiştir $(2,3)$. Akciğerde "neutrophil extracellular traps" (NETs) oluşumunun COVID-19 enfeksiyonunun belirleyici özelliği olduğu bildirilmektedir. Pulmoner kapillerlerde süreç 'kapilleritis', fibrin depozisyonu, nötrofil ekstravazasyonu ile gitmektedir.
2011 'de inhalasyon yoluyla verilen dornaz alfa'nın KF'li çocuklarda NET'leri parçalayarak hava yolunu açtığı ve semptomları düzelttiği bildirilmiştir (4).

2000'li yıllarda Dornaz alfa'nın diğer tedavilere dirençli non-kistik fibrozisli bebeklerde erken dönem atelektatik akciğerde solunum işlevlerini iyileştirdiği gösterilmiştir $(5,6)$.

\section{TANIM VE ETKI MEKANIZMASI}

İnsan deoksiribonükleaz I (rhDNaz I) rekombinant teknoloji ile üretilen ve DNA'yı selektif parçalayan bir enzimdir. Dornaz alfa denen bu ajan, kistik fibrozis (KF) hastalarının akciğerindeki balgam veya mukusunda bulunan DNA'y1 parçalar, hidrolize eder; sonuçta akciğerlerdeki sıvının viskozitesini azaltır. Ajan bu yolla salgıların daha etkin drene olmasına izin verir (Şekil 2).

rhDNaz I KF'li çocuklarda balgam viskoelastisitesini azaltmada, hava yollarını açmada etkili bulunmuştur. Bunu yıkılan lökositlerden ve epitel kalıntılarından 


\section{Karcıoğlu}

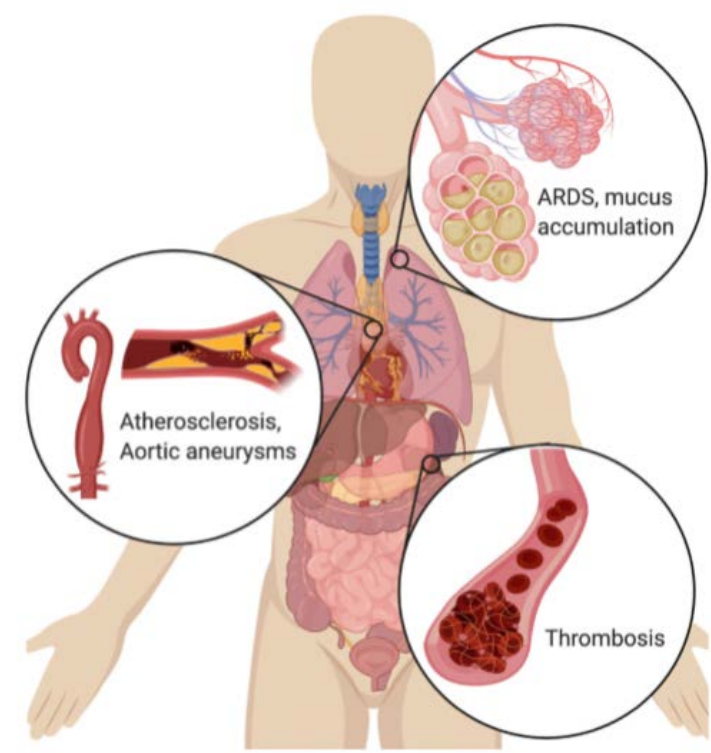

Şekil 1: Kistik fibrozis ve COVID-19 olgularının patofizyolojisinde suçlanan "neutrophil extracellular traps" (NETs) akciğerde mukus tıkaçları ve ARDS oluşumu dışında ateroskleroz, mikrotrombozis ve anevrizma oluşumunda da rol oynamaktadır.

açığa çıkan ekstrasellüler DNA'yı parçalayarak yapmaktadir (7).

Türkiye'de 2013'te yapılan küçük örneklemli bir çalışmada YBÜ'de yatan, akciğer atelektazisi olan 23 yenidoğana rhDNase tedavisi nebulize ve intratrakeal yoldan uygulanmıştır (8). rhDNase tedavisine alınan olumlu radyolojik ve klinik yanıt ile atelektazinin tekrarlama oranları sirasıly $\% 78,3, \% 56,3$ ve $\% 16,7$ olarak kaydedilmiştir. Özellikle yapışkan salgıları, pnömonisi ve üst akciğer loblarında persistan atelektazisi olan yenidoğanlarda rhDNase'ın uygulamaları başarılı bulunmuştur. Herhangi bir yan etki bildirilmemiştir. Alt analizde nebulize uygulama intratrakeal uygulamadan daha başarılı bulunmuştur. Bu özellikler taşıyan yenidoğanlarda kullanılması önerilmiştir.

Dornaz alfa'nın KF tedavisinde olduğu gibi COVID-19 hastalarında da mukus salgısını parçalayıp akciğer işlevini geri döndürmede etkili olabileceği ortaya atılmıştır. Bunun kanıtları henüz net olarak ortaya konamamıştır.

Yakın zamanda çocuklarda plevral ampiyem tedavisinde de Dornaz alfa kullanımı çalışılmıştır. Livingston ve ark. t-PA tedavisine ek olarak intraplevral DNAse verilmesinin ek yararı olmadığını bildirmiştir (9).

ARDS ve Dornaz alfa: Travma, suda boğulma, yanık gibi farklı etiyolojilerin akciğerde ARDS'ye yol açarak solunum yetmezliğini tetiklediği bilinmektedir. COVID-19 olgularında da NET oluşumu, damageassociated molecular patterns (DAMPs) ve ilişkili mekanizmalarla ARDS başladı̆̆ında prognozun kötüleştiği ortaya konmuştur. DAMP'lar NET'e bağlanmakta ve akciğerdeki tıkaç oluşumunu tetiklemektedir. Lökositlerden açığa çıkan çift sarmallı DNA'lar da bu oluşumu hızlandırmaktadır. Dornaz alfa'nın bu DNA'ları parçalayarak ARDS başlamasını engellemesi veya geciktirmesi düşüncesi hipotez olarak ortaya atılmış ve TRAUMADORNASE gibi çok merkezli iyi tasarlanmış çalışmalara öncülük etmiştir.

ARDS hastalarında bu NET oluşumunun belirgin şekilde fazla bulunduğu kesinleşmiştir (10). Transfüzyon-ilişkili ARDS'de de plazmada NET'lerin ARDS olmayanlara göre fazla bulunduğu da bildirilmiştir (11).

\section{Diğer virüs hastalıklarında Dornaz alfa}

Ajan solunum yolunu tutan diğer virüslerde de NET oluşumu ve buradaki DNA yapılarını parçalamada kullanılmıştır. Cortjens ve ark. 2018 yılında kuzularda şiddetli RSV enfeksiyonlarda NET'lerin tetiklediği solunum yolu tıkanmasında Dornase alfa tedavisinin güçlü ve anlamlı iyileşmeye yol açtığını bildirmiştir (12). Kontrol ve tedavi gruplarının viral yükleri benzer bulunmuştur. Yazarlar bu nedenle NET'lerin şiddetli RSV enfeksiyonunda önemli bir tedavi hedefi olabileceğini belirtmişlerdir (12).

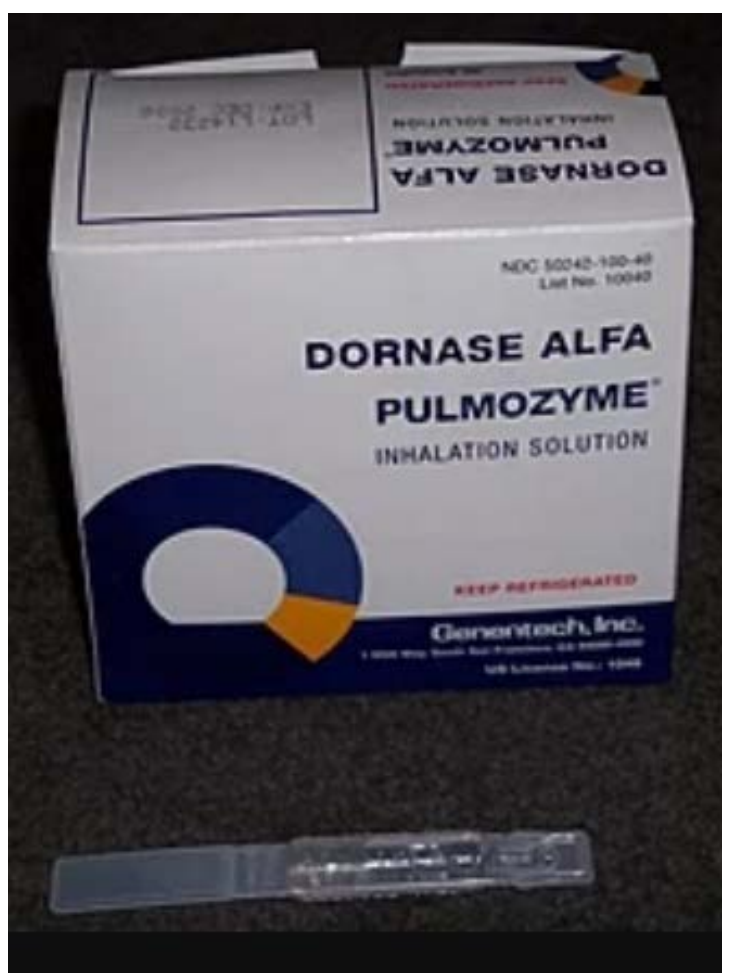

Şekil 2: Dornaz-Alfa olarak bilinen, insan deoksiribonükleaz I (rhDNaz I) rekombinant teknoloji ile üretilen bir ajandır. 


\section{NEGATIF YÖNLERI}

- Pahalidir.

- Nebülizasyon yoluyla kullanılması başı başına bir sorundur. Bu yol aerosolizasyon nedeniyle virüs geçişinin ana mekanizması olduğundan sağlık ekibinin çok iyi önlem almaması durumunda yayılım ile sonuçlanabilir. Az kullanılmasının ana nedeninin bu olduğu düşünülebilir (1).

- ARDS dışındaki olgularla ilgili elde net kanıt yoktur, dolayısıyla hafif-1lımlı şiddette COVID-19 geçiren olgulara uygulanması ile ilgili bir öneri yoktur.

\section{Kimlerde dikkatli olunmalıdır?}

Yumurta allerjisi dişında önemli bir kontrendikasyon veya çekinilecek durum söz konusu değildir.

\section{SONUÇ}

Dornaz alfa KF olgularında, ARDS'yi tetikleyerek solunum yolu tıkanıklığına yol açan hastalıklarda ve başka bazı viral enfeksiyonlarda solunum yetmezliğini engellemede ümit verici sonuçlar almamızı sağlamıştır. Ancak COVID-19, bununla ilişkili ARDS ve sonuçta ortaya çıkan akut solunum yetmezliği üzerine etkisi henüz netleşmemiştir. COVID-19 dornaz alfa için çok merkezli iyi tasarlanmış çalışmalarla ortaya konuncaya kadar net bir kullanım alanı değildir.

\section{KAYNAKLAR}

1. Barnes BJ, Adrover JM, Baxter-Stoltzfus A, et al. Targeting potential drivers of COVID-19: Neutrophil extracellular traps J Exp Med. (2020) 217 (6): e20200652

2. Fox SE, Akmatbekov A, Harbert JL, Li G, Quincy Brown J, Vander Heide RS. Pulmonary and cardiac pathology in African American patients with COVID-19: an autopsy series from New Orleans [published online ahead of print, 2020 May 27]. Lancet Respir Med. 2020;S2213-2600(20)30243-5. doi:10.1016/S2213-2600(20)30243-5

3. Yao XH, Li TY, He ZC, et al. [A Pathological Report of Three COVID-19 Cases by Minimal Invasive Autopsies] [Article in Chinese] Zhonghua Bing Li Xue Za Zhi. 2020;49(5):411-417. doi:10.3760/cma.j.cn112151-20200312-00193

4. Papayannopoulos, V., D. Staab, and A. Zychlinsky. 2011. Neutrophil elastase enhances sputum solubilization in cystic fibrosis patients receiving DNase therapy. PLoS One. 2011;6(12):e28526.

5. Erdeve O, Uras N, Atasay B, Arsan S. Efficacy and safety of nebulized recombinant human DNase as rescue treatment for persistent atelectasis in newborns: case-series. Croat Med J. 48 (2),234-9. 2007.

6. Hendriks T, de Hoog M, Lequin MH, Devos AS, Merkus PJ. DNase and atelectasis in non-cystic fibrosis pediatric patients. Crit Care. 9 (4), R351-6. 2005.

7. Fitzgerald DA, Hilton J, Jepson B, Smith L. A crossover, randomized, controlled trial of dornase alfa before versus after physiotherapy in cystic fibrosis. Pediatrics 2005;116(4):e549-54.

8. Çalkavur Ş, Olukman Ö, Ercan G, et al. Practice of Intratracheal and Inhaled Recombinant Human Deoxyribonuclease (rhDNase) Therapy in Neonates with Persistent Atelectasis: A Rescue Treatment. Turkiye Klinikleri J Med Sci. 2013;33(4):1143-50.

9. Livingston MH, Mahant S, Connolly B, et al. Effectiveness of Intrapleural Tissue Plasminogen Activator and Dornase Alfa vs Tissue Plasminogen Activator Alone in Children with Pleural Empyema: A Randomized Clinical Trial. JAMA Pediatr 2020 Feb 3. doi: 10.1001/jamapediatrics.2019.5863. [Epub ahead of print]

10. Lv, X., T. Wen, J. Song, D. Xie, L. Wu, X. Jiang, P. Jiang, and Z. Wen. 2017. Extracellular histones are clinically relevant mediators in the pathogenesis of acute respiratory distress syndrome. Respir. Res. 18:165. https://doi.org/10.1186/s12931-017-0651-5

11. Caudrillier, A., K. Kessenbrock, B.M. Gilliss, J.X. Nguyen, M.B. Marques, M. Monestier, P. Toy, Z. Werb, and M.R. Looney. 2012. Platelets induce neutrophil extracellular traps in transfusion-related acute lung injury. J. Clin. Invest. 122:2661-2671. https://doi.org/10.1172/JCI61303

12. Cortjens B, de Jong R, Bonsing JG, van Woensel JBM, Antonis AFG, Bem RA. Local dornase alfa treatment reduces NETs-induced airway obstruction during severe RSV infection. Thorax 2018 Jun;73(6):578-580. doi: 10.1136/thoraxjnl-2017-210289. Epub 2017 Aug 5. 